\title{
Pattern of Fruit Drop, Yield, Maturity and Harvesting of Different Varieties of Ber (Ziziphus mauritiana Lamk.) in New Alluvial Zone of West Bengal
}

\author{
T. Adhikary*, S. Kundu, S. Shivakumar and B. Ghosh
}

Department of Fruits and Orchard Management, Bidhan Chandra Krishi Viswavidyalaya, Mohanpur, West Bengal (741 252), India

\section{Keywords}

Zizyphus mauritiana, Fruitdrop, Fruit retention, Maturity, Yield

Article Info

Accepted:

17 November 2019

Available Online:

10 December 2019

\section{A B S T R A C T}

An investigation was carried out at Horticultural Research Station, Mondouri, North 24 Parganas, B.C.K.V., West Bengal, India during 2015-16 with fourteen cultivars of ber to understand and provide a wealth of usable information of ber breeding programme. All the varieties showed wide variation of fruit set (3.9$31.4 \%)$, fruit drop (63.085.5\%) and retention (14.5-36.9\%). Higher percentage of fruit set was noted in Sanur-2 (31.4\%), BAU-1 Kul (26.5\%), Umran (26.1\%), Banarasi Karaka (24.8\%). A large percentage of fruit dropped before reaching the maturity stage. However, the heaviest drop was recorded in the variety Banarasi Karaka and minimum in Umran. In all the cultivars the fruit drop was maximum up to 30 days after fruit set, declining later on. In Sanur-2 the fruit set percentage was highest but fruit retention was not up to the mark. Fruit maturity among 14 varieties was 111 to 149 days with a longer period of harvesting (21-37 days) and wide range of yield (15.96 to $46.36 \mathrm{~kg} / \mathrm{tree}$ ). BAU-1 Kul, Gola and Jogia were harvested earlier and Apple Kul, Banarasi Karaka Madhabpur, Mundia, Umran were harvested late. Duration of harvesting was longest in Illaichi. Umran and Topa were higher in fruit yield (46.36 kg and $43.77 \mathrm{~kg} /$ plant, respectively).

\section{Introduction}

Ber (Ziziphus mauritiana Lamk.) is one of the ancient and indigenous fruits of India. It belongs to family Rhamnaceae and order Rhamnales $(2 n=48)$. In India, cultivated ber has more than 300 varieties but only a few are commercially important (Pareek and Nath, 1996). The majority of varieties of Indian jujube are selection from heterogeneous population. Plant breeders look for ideal plant types or ideotypes in order to combine maximum desirable traits in a cultivar. So, improvement is needed to incorporate the resistance to major pest and diseases, adapt some cultivars to particular environmental stresses and to improve the quality of fruits besides yield increase. Performance of ber in 
new alluvial zone of West Bengal was previously studied by Kumar et al., (2017), but this study is based on vegetative characters and fruit quality attributes. Hybridization is one of the most important methods for bringing improvement in fruit crops. For efficient and purposeful breeding programme, it is necessary to have knowledge of proper reproductive characters, this is essential prerequisite for a successful hybridization programme.High genetic variation exists in $Z$. mauritiana germplasm because of cross pollination, self-incompatible and polyploidy in nature. These genetic variability provide ample opportunities for selection of genotypes for desirable traits (Vashishtha and Pareek, 1989; Vashishtha, 2001; Khan et al., 2013).Awasti and More (2009) had already studied the wide genetic diversity and status of ber in India. As no information available still now in new alluvial zone of West Bengal, an experiment was laid out by Randomized block design (RBD) with three replication and fourteen varieties (Apple Kul, Banarasi Karaka, BAU-1 Kul, Chhuhara, Dandan, Gola, Illaichi, Jogia, Kaithali, Madhavpur, Mundia, Sanur-2, Topa and Umran). For efficient and purposeful breeding programme, it is necessary to have knowledge of fruit set, fruit drop, yield, maturity and harvesting of different varieties in the specific region where the crop has grown. It is also formulate the appropriate cultural practices that may influence the fruit yield and quality. Previous study on varietal evolution of ber on yield and yield attributing parameter were studied by Tarai and Ghosh (2010) but in new alluvial zone of West Bengal no studies was yet documented. So there is an urgent need to study on such yield attributing parameter in this region.

\section{Materials and Methods}

The investigation was carried out on the ber orchard at Horticultural Research Station,
Mondouri of Bidhan Chandra Krishi Viswavidyalaya, Nadia, West Bengal during the year 2014-16. The ber orchard is situated at the eastern side of this research station having $22.43{ }^{0} \mathrm{~N}$ latitude and $88.34{ }^{0} \mathrm{E}$ longitude, with an altitude of $9.75 \mathrm{~m}$ above the mean sea level.

\section{Climatic condition during the experimental period}

The experimental site comes under subtropical humid climate as it is situated just south of tropic of cancer. There five distinct seasons namely summer $\left(16^{\text {th }}\right.$ April $-10^{\text {th }}$ of June), rainy season $\left(11^{\text {th }}\right.$ June to $30^{\text {th }}$ September), autumn ( $1^{\text {st }}$ October $-15^{\text {th }}$ December), winter season $\left(15^{\text {th }}\right.$ December $15^{\text {th }}$ February) and spring season $\left(16^{\text {th }}\right.$ of February - 15th of April). During the period of investigation maximum temperature was recorded $\left(34.3^{\circ} \mathrm{C}\right)$ in the month of March 2016, while minimum temperature was recorded $\left(11.9^{\circ} \mathrm{C}\right)$ in the month of January 2016. Humidity was maximum (96\%) in the month of September 2015, While minimum (47.4\%) in the month of March 2016. Maximum rainfall $(193.6 \mathrm{~mm})$ occurred in August 2015. Metrological data during the research work was collected from the Department of Agricultural Meteorology and Physics, Bidhan Chandra Krishi Viswavidyalaya, Faculty of Agriculture, Mohanpur, Nadia, West Bengal. The data for the Climatic parameters has been presented in Table 1. Maximum and minimum temperature (Table 1) percentage of maximum and minimum Humidity (Table 1) average rainfall (cm) (Table 1) data has been represented graphically also.

\section{Experimental design}

The experiment was laid out with 14 varieties (Apple Kul, Bnarasi Karaka, BAU-1 Kul, Chhurahara, Dandan, Gola, Illaichi, ogia, 
Kaithali, Madavpur, Mundia, Sanur-2, Topa, and Umran) in a randomised block design. Each variety was replicated thrice. Fruit set, drop and retention

\section{Fruit set}

Branchlets were tagged consisting of about 200 open flowers in all directions for each plant during peak flowering season. Remove all flower buds and tiny fruits from branchlets, if any. Fruit set were counted at fruits of lentil size.

\section{Fruit drop}

In order to ascertain the extent of drop in different varieties, branches were tagged consisting of 200 fruits of lentil size in all directions during peak fruiting season for each plant. Fruit drops were recorded at 30 days, 60 days and 90 days after fruit.

\section{Fruit retention}

The fruits left after fruit drop in December were considered as the fruit retention among different varieties.

\section{Fruit maturity}

Branchlets consisting of only set fruits of uniform lentil size were tagged. Flower buds and fruit of higher size were removed from branchlet. The days required for fruit set to its full development (edible stage) was considered as period of fruit maturity.

\section{Harvesting}

Maturity of at least first 10 fruits in a plant and last 10 matured fruits in a plant were considered as start and end of harvesting, respectively. The period between start and end of harvesting was considered as the duration of harvesting. The variety matured in the last week of December to first week of February was considered as early variety. The variety matured in the 3rd week of January onwards up to 3rd week of February was considered as mid-season variety.

The variety harvested in between last week January to first week of March was placed under late season.

\section{Yield}

Fruit yield was recorded by weight. The quantitative or measured data obtained were analysed statistically by the analysis of variance method as suggested by Panse and Sukhatme (1978) and the significance of different source of variation was tested by error mean square by Fisher's ' $F$ ' test of probability level of 0.05 percent.

\section{Results and Discussion}

\section{Fruit set}

The data on percentage of fruit set is presented in Figure $1 \mathrm{~A}$. There was a marked variation in fruit set in different cultivars which ranged from $3.9 \%$ Chhuhara to $31.4 \%$ in Sanur-2.

The higher fruit set was also recorded in BAU Kul-1 (26.5 \%), Umran (26.1\%), Banarasi Karaka (24.8\%), Dandan (23.3\%), Topa (23.1\%), Illaichi (21.4\%), Madhavpur (20.8\%) and Jogia (20.4\%).

\section{Fruit drop at 30 days after fruit set (DAFS)}

There were significant differences in the extent of fruit drop in different cultivars, showed in Figure 2 B. A very heavy fruit drop occurred immediately after fruit set (30 days after fruit set), being maximum in Dandan $(72.3 \%)$ and minimum in Madhavpur (41\%). More than $40 \%$ fruit drop is occurred when the fruits are in pea size. 


\section{Fruit dropat 60 days after fruit set (DAFS)}

As fruit development advanced, percent of fruit drop was reduced. Fruit drop was ranged from $55.4 \%$ in Umran to $81.2 \%$ in Banarasi Karaka in 60 days after fruit set (Fig. 2 B).

Mundia, Dandan and Ellaichi also showed higher rates of fruit drop that was $77.9 \%$, $77.2 \%$ and $75.7 \%$ respectively. Topa, Madhavpur and Sanur-2 showed lower rates of fruit drop that was $57.1 \%, 61.2 \%$ and $63.2 \%$ respectively.

\section{Fruit drop at 90 days after fruit set (DAFS)}

More than $80 \%$ fruit drop was noticed in Illaichi (81.9\%), Mundia (82.8\%), Dandan $(84.5 \%)$, Banarasi Karaka $(85.5 \%)$ and more than $70 \%$ fruit drop recorded in Madhavpur (70.2\%), Sanur-2 (71.5\%), Chhuhara (72.7\%), Kaithali (74.5\%), Jogia (76\%), Apple kul (77.2\%), BAU Kul-1 (77.5\%), Gola (78.2\%) in 90 days after fruit set (Fig. 2 B). Minimum fruit drop occurred in Umran(63\%).

\section{Fruit retention}

The percentage fruit retention is very low, ranged between $14.5 \%$ in Banarasi Karaka to $36.9 \%$ in Uman (Table 1).

The higher fruit retention was observed in in Topa (35.4\%), Madhavpur (29.8\%), and Sanur-2 (28.5\%).

The lower fruit retention was observed in Illaichi (18.1\%), Mundia (17.2\%) and Dandan (15.4\%).

\section{Fruit maturity}

The detail of fruit maturity period is presented in Table 2. The number of days required for the development of fruit was longest (149 days) in Apple kul and shortest (111 days) in BAU Kul-1.

\section{Harvesting season}

Table 2 represent the harvesting season of different ber varieties. BAU Kul-1, Gola and Jogia cultivars were identified as early season cultivar as they are matured in last week of December to first week February. Chhuhara, Dandan, Illaichi, Kaithali, Sanur-2 and Topa considered as mid-season cultivar as they matured in 3rd week of January onwards up to 3rd week of February. Apple kul, Banarasi Karaka, Madhavpur, Mundia and Umran matured during the period of last week January to first week of March is considered as the late season cultivar.

\section{Duration of harvesting}

Harvesting period of ber ranged between 21days to 37 days (Table 2). The longest total time period taken for fruit harvesting was observed in BAU Kul-1 i.e., 37 days which ranged from 22nd December to 27th January. The shortest total time period for harvesting was recorded in Dandan i.e., 21 days ranging from 19th January to 8th February.

\section{Yield}

Wide and Significant variation in yields (15.96 to $46.36 \mathrm{~kg} /$ tree) had been observed among different ber cultivars (Figure $2 \mathrm{~B}$ ). Highest yields are obtained from Umran (46.36 kg/tree) followed by Topa (43.77 $\mathrm{kg} /$ tree) and Sanur-2 (41.48 kg/ tree). Lowest yield was obtained from Chhuhara (15.95 $\mathrm{kg} /$ tree), Illaichi (17.44 kg/tree).

\section{Correlation}

There is a positive significant relationship between Fruit retention with fruit set (Table 3 ). It was found that there were high negative correlation between fruit drop with fruit set and also in fruit drop and fruit retention. Yield has both significant positive relationship with 
fruit set and fruit retention but has inverse relationship with Fruit drop.

Results revealed from the present studies on reproductive variability of ber in new alluvial zone of West Bengal indicated that there was a wide variation among fourteen varieties in respect of flowering behaviour, floral bud development, flower morphology, sex ratio, intensity of flowering, fruit set, fruit drop and yield.

All the varieties showed wide variation of fruit set (3.9-31.4\%), fruit drop (63.0-85.5\%) and retention (14.5-36.9\%). Higher percentage of fruit set was noted in Sanur-2 (31.4\%), BAU Kul-1 (26.5 \%), Umran (26.1\%), Banarasi Karaka $(24.8 \%)$. Flowering in ber, in general, was very profuse but the life of the individual flower was very short and many flowers apparently were not pollinated during their receptive period resulted in such a low fruit set. A large percentage of fruit dropped before reaching the maturity stage. However, the heaviest drop was recorded in the variety Banarasi Karaka $(85.5 \%)$ and minimum in Umran (63.0\%). The fruit drop in Banarasi Karaka was $85 \%$ in Delhi (Sharma et al., 1990), 55\% at Hissar (Singh et al., 1970) and $64 \%$ in Uttar Pradesh (Teatotia and Chauhan, 1964) In all the cultivars the fruit drop was maximum up to 30 days after fruit set, declining later on. Ovule disintegration may be the major cause of fruit drop during early stage of fruit development. Teaotia and Chuhan (1963) also observed the heaviest fruit drop during early stages of fruit development. Fruit retention was much higher in Topa and Umran. It could also be observed that initially higher fruit set does not necessarily lead to higher fruit retention. In Sanur-2 the fruit set percentage was highest but fruit retention was not up to the mark. These findings are also supported by Sharma et al., (1990).
Fruit maturity among fourteen varieties was 111 to 149 days with a longer period of harvesting (21-37 days) and wide range of yield (15.96 - $46.36 \mathrm{~kg} /$ tree). Harvesting of different varieties started from $22^{\text {nd }}$ December and continued up to $2^{\text {nd }}$ March. Sharif et al., (2013) reported that total time period taken for fruit harvesting ranged from 20th February to 10th April BAU-1 Kul, Gola and Jogia were harvested earlier and Apple kul, Banarasi Karaka Madhabpur, Mundia, Umran were harvested late. Neeraja et al., (1995) also found that in Gola fruits matured earlier than those of all other cultivars. But in Bangladesh condition, Apple kul was earliest to harvest (Islam, 2007). Sharif et al., (2013) also reported that the longest time period of 27 days for fruit harvesting was observed in Bahawalpur Selection 2 (25th February to 23rd March). The shortest time period of 8 days for harvesting was recorded in Ajooba (11 ${ }^{\text {th }}$ March to $19^{\text {th }}$ March). It was found that duration of harvesting was longest in case of Illaichi 35 days ( $12^{\text {th }}$ January to 15 th February) and shortest in case of Dandan 21 days $\left(19^{\text {th }}\right.$ January to $8^{\text {th }}$ February). Umran and Topa were higher in fruit yield $(46.36 \mathrm{~kg}$ and 43.77 kg/plant, respectively).Mandal et al., 2009 and Kumar et al., 2017also found similar yield pattern of different ber varieties $(50.8 \mathrm{~kg} /$ plant to $42.8 \mathrm{~kg} / \mathrm{plant}$ ) in alluvial zone of West Bengal. In contrast much higher yield was obtained by Teaotia and Chuhan (1963), Bakhshi and Singh (1974) and Kumar et al., (1986). However almost similar yield of Umran in the present studies was also obtained by Rao and Subramanyam (2010).

All the varieties showed wide variation of fruit set (3.9-31.4\%), fruit drop (63.0-85.5\%) and retention (14.5-36.9\%). Higher percentage of fruit set was noted in Sanur-2 (31.4\%), BAU-1 Kul (26.5\%), Umran (26.1\%), Banarasi Karaka (24.8\%). 
Table.1 Meteorological data of experimental area during period of investigation

\begin{tabular}{|c|c|c|c|c|c|c|c|}
\hline \multirow{2}{*}{ Year } & Month & \multicolumn{3}{|c|}{ Temperature $\left.\mathbf{(}^{\mathbf{0}} \mathbf{C}\right)$} & \multicolumn{2}{|c|}{ Relative humidity (\%) } & Rainfall \\
\cline { 3 - 8 } & & Max. & Min. & & Max. & Min. & 193.6 \\
\hline \multirow{3}{*}{2015} & August & 33.4 & 26.8 & & 94.8 & 76.8 & 227.3 \\
\cline { 2 - 8 } & September & 34.0 & 26.1 & & 96.0 & 71.0 & 41.6 \\
\cline { 2 - 8 } & October & 33.4 & 23.7 & & 94.2 & 62.5 & 0.0 \\
\cline { 2 - 8 } & November & 31.4 & 18.8 & & 93.3 & 52.9 & 6.6 \\
\cline { 2 - 8 } & December & 26.3 & 15.0 & & 93.1 & 56.3 & 3.0 \\
\hline \multirow{2}{*}{$\mathbf{2 0 1 6}$} & January & 25.8 & 11.9 & & 92.8 & 53.3 & 28.0 \\
\cline { 2 - 8 } & February & 30.3 & 18.4 & & 92.8 & 53.9 & 35.8 \\
\hline
\end{tabular}

Source: Department of Agro-Meteorology and Physics, BCKV, Mohanpur, Nadia, West

Table.2 Fruit maturity harvesting of different varieties of ber

\begin{tabular}{|c|c|c|c|c|c|}
\hline \multirow[b]{2}{*}{ Variety } & \multirow{2}{*}{$\begin{array}{c}\text { Fruit } \\
\text { Maturity } \\
\text { (days) }\end{array}$} & \multicolumn{4}{|c|}{ Harvesting } \\
\hline & & $\begin{array}{c}\text { Start of } \\
\text { harvesting }\end{array}$ & $\begin{array}{c}\text { End of } \\
\text { harvesting }\end{array}$ & $\begin{array}{l}\text { Duration of } \\
\text { harvesting } \\
\text { (Days) }\end{array}$ & $\begin{array}{c}\text { Harvesting } \\
\text { season }\end{array}$ \\
\hline Apple kul & 149 & 04.02 .2016 & 02.03 .2016 & 28 & Late \\
\hline $\begin{array}{c}\text { Banarasi } \\
\text { Karaka }\end{array}$ & 144 & 31.01 .2016 & 28.02 .2016 & 29 & Late \\
\hline BAU Kul-1 & 111 & 22.12.2015 & 27.01 .2016 & 37 & Early \\
\hline Chhuhara & 128 & 26.01 .2016 & 17.02 .2016 & 23 & Mid \\
\hline Dandan & 119 & 19.01.2016 & 8.02 .2016 & 21 & Mid \\
\hline Gola & 141 & 07.01 .2016 & 30.01 .2016 & 24 & Early \\
\hline Illaichi & 113 & 12.01.2016 & 15.02 .2016 & 35 & Mid \\
\hline Jogia & 110 & 11.01.2016 & 01.02 .2016 & 22 & Early \\
\hline Kaithali & 119 & 18.01.2016 & 08.02 .2016 & 22 & Mid \\
\hline Madhavpur & 147 & 07.02 .2016 & 01.03 .2016 & 24 & Late \\
\hline Mundia & 146 & 01.02 .2016 & 27.02 .2016 & 27 & Late \\
\hline Sanur-2 & 128 & 18.01 .2016 & 08.02 .2016 & 22 & Mid \\
\hline Topa & 121 & 12.01 .2016 & 8.02 .2016 & 28 & Mid \\
\hline Umran & 148 & 01.02 .2016 & 29.02 .2016 & 29 & Late \\
\hline $\operatorname{SEm}( \pm)$ & - & - & - & - & - \\
\hline LSD (0.5) & - & - & - & - & - \\
\hline
\end{tabular}


Fig.1 Variation in Fruit set and Fruit retention among all the varieties of ber. Vertical bars represent \pm S.E. of means for 3 replicates (A). Linear regression relationship between Fruit firmness and Fruit Set (B)

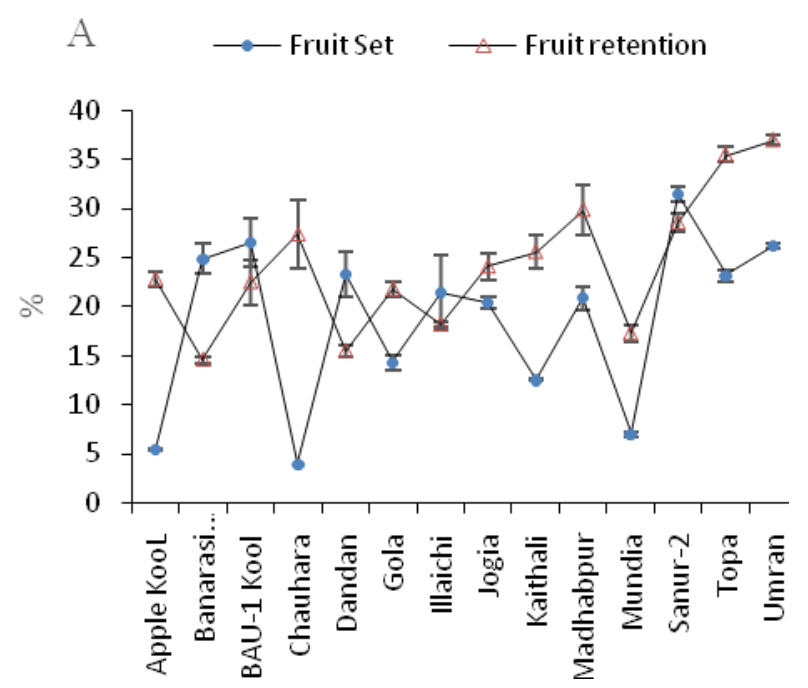

$\mathrm{B}$

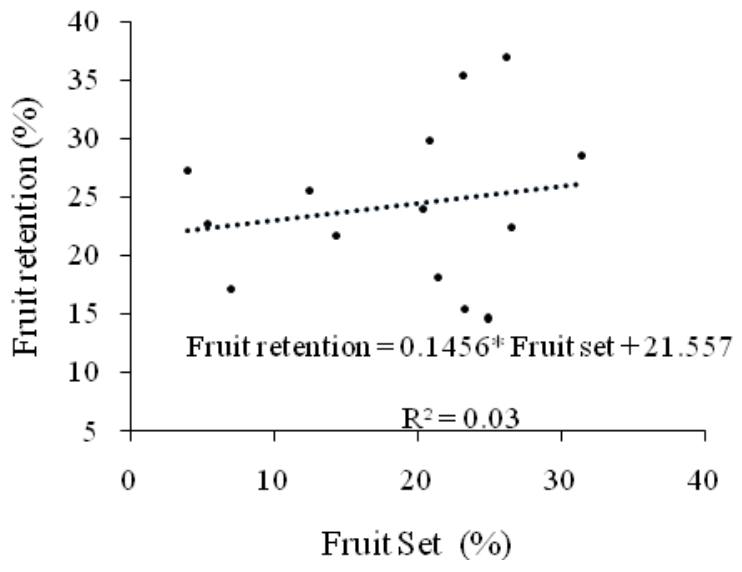

Fig.2 Variation in Fruit yield among different varieties of ber. Vertical bars represent \pm S.E. of means for 3 replicates (A). Fruit drop patteren in different days interval among different varieties (B)
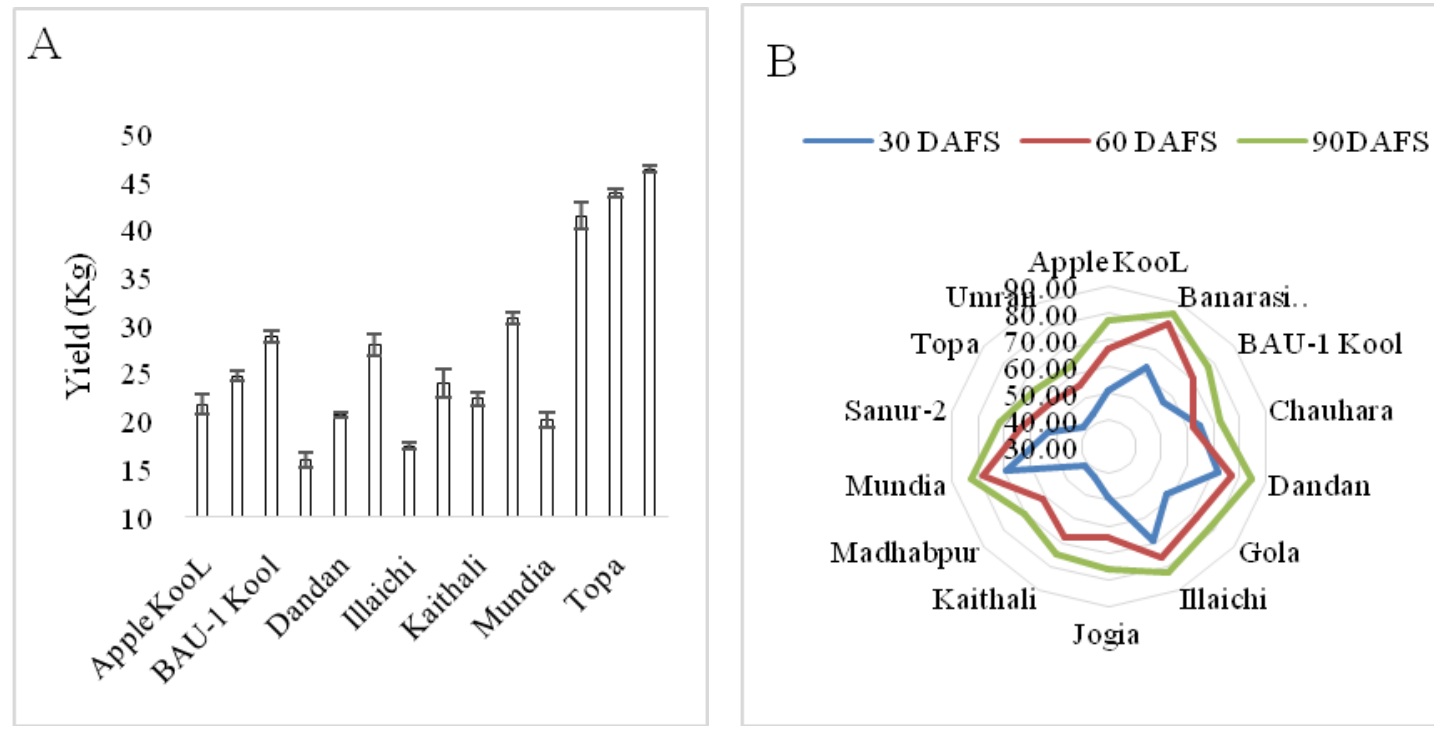
Table.3 Pearson's correlation coefficients among different parameters

\begin{tabular}{|c|c|c|c|c|}
\hline & Fruit Set & $\begin{array}{c}\text { Fruit } \\
\text { retention }\end{array}$ & Fruit drop & Yield \\
\hline Fruit Set & 1 & & & \\
\hline Fruit retention & 0.182 & 1 & & \\
\hline Fruit drop & -0.167 & -0.955 & 1 & \\
\hline Yield & 0.631 & 0.757 & -0.710 & 1 \\
\hline
\end{tabular}

Significant at $\mathrm{P}<0.01$ level

A large percentage of fruit dropped before reaching the maturity stage. However, the heaviest drop was recorded in the variety Banarasi Karaka and minimum in Umran. In all the cultivars the fruit drop was maximum up to 30 days after fruit set, declining later on. In Sanur-2 the fruit set percentage was highest but fruit retention was not up to the mark. Fruit maturity among 14 varieties was 111 to 149 days with a longer period of harvesting (21-37 days) and wide range of yield (15.96 to $46.36 \mathrm{~kg} /$ tree).

BAU-1 Kul, Gola and Jogia were harvested earlier and Apple Kul, Banarasi Karaka Madhabpur, Mundia, Umran were harvested late. Duration of harvesting was longest in Illaichi. Umran and Topa were higher in fruit yield $(46.36 \mathrm{~kg}$ and $43.77 \mathrm{~kg} / \mathrm{plant}$, respectively).It is concluded that there is a wide variation of reproductive characters among different varieties. This knowledge of reproductive characters will be useful for efficient and purposeful breeding programme as well as for using these varieties as desirable parent.

\section{References}

Awasthi O.P. and More T.A. (2009). Genetic diversity and status of Ziziphus in India. ActaHortic. 840:33-40.

Bakhshi J. C. and Singh P. (1974). The ber a good choice for semi-arid and marginal soils. Indian Hort., 19: 27-30.

Khan H., Sivalingam P.N., Chauhan S.,
Awasthi O.P., More T.A. (2013). Improved crossing technique and identification of true F1 hybrids of Ziziphus mauritiana Lam. by molecular markers. Scientia Horticulturae. 150: 164-171

Kumar S.S., Babu R.S. and Reddy Y.N. (1986). Duration of fruit maturity seasons and yield of certain cultivars of ber (Ziziphus mauritiana Lamk.) at Hyderabad. J. Res., 14 (1): 88-89.

Kumar S.S, Kundu S., Nandi, P., Shekhar, R.T, Adhikary, K, Ghosh B., Dutta P. (2017). Performance of ber in New alluvial zone of West Bengal. J. Crop Weed. 13 (1):189-191.

Mandal K.K., Mania $M$ and Hasan M.A. (2009). Evaluation of ber cultivars for growth, yield and quality in red and laterite zone of West Bengal. (2009). J. Crop Weed 5:171-172.

Neeraja G., Reddy S.A. and Babu R.S.H. (1991). Studies on Floral Biology of ber cultivars 'Seb'. J. Res., 21(4): 24345.

Neeraja G., Reddy S.A. and Babu R.S.H. (1995). Fruit set, fruit drop and fruiting behaviour in certain ber (Ziziphus mauritiana Lamk.) cultivars. J. Res., 23(3/4):17-21.

Panse, V.G. and Sukhatme, P.V. (1978) Statistical methods for agricultural workers. ICAR,

Pareek O.P. and Nath V. (1996). Ber: Coordinated fruit research in Indian arid zone National research centre for 
arid Horticulture, India. pp 9-30

Sharif N., Jaskani M.J., Memon N., Alwi M., Bloch D.M., Abbas M.M. and Ishfaq M. (2013). Categorization of ber varieties in relation to blooming period, fruit setting and harvesting time. Pakistan. J. Agri. Sci., 50(3): 407-413.

Sharma V.P., Raja P.V. and Kore V.N. (1990). Flowering, fruit set and fruit drop in some ber (Ziziphus mauritiana Lamk.) varieties. Annals Agric. Res. Inst., 11(1), 14-20.

Singh D. and Jindal P.C. (1982). Studies on flowering and sex ratio in some ber (Ziziphus mauritiana Lamk) cultivars. Haryana Agric. Univ. J. Res., 12(2): 292-294.

Singh, D.Bakshi J.C. and Singh (1970). Flowering and fruiting behaviour of ber, variety Banarasi Karaka (Zizyphus mauritiana Lam.). Pub. Hort. J.., 10: 21-28.

Tarai R. K. and Ghosh S.N (2010). Varietal evaluation for yield and yield parameters of ber under semi-arid region of West Bengal. J. Hortl. Sci. 5 (1): 17-20.

Teaotia S.S. and Chauhan R.S. (1963). Flowering, Pollination, fruit set and fruit drop studies in ber (Ziziphus mauritiana Lamk.) I. Floral Biology. Punjab Hort. J., 3: 60-70.

Teaotia S.S. and Chauhan R.S. (1964). Flowering, Pollination, fruit set and fruit drop studies in ber (ZiziphusmauritianaLamk.) II. Pollination, fruit set, fruit development and fruit drop. Indian J. Hort., 2: 4045.

Vashishtha B.B. and Pareek O.P. (1979). Flower morphology, fruit set and fruit drop in some ber (Ziziphus mauritiana Lamk.) cultivars. Annals Arid Zone. 18(3): 165-169.

Vashishtha B.B., Pareek O.P., (1989). Identification key for the cultivars of Indian Jujube (Ziziphus mauritiana Lamk.). Indian J. Hortic. 46:183-188.

Vashishtha B.B. (2001). Ber varieties, a monograph. Agrobios (India), Jodhpur, pp97.

\section{How to cite this article:}

Adhikary, T., S. Kundu, S. Shivakumar and Ghosh, B. 2019. Pattern of Fruit Drop, Yield, Maturity and Harvesting of Different Varieties of Ber (Ziziphus mauritiana Lamk.) in New Alluvial Zone of West Bengal. Int.J.Curr.Microbiol.App.Sci. 8(12): 2249-2257. doi: https://doi.org/10.20546/ijcmas.2019.812.267 